\title{
A heart made of habhab but with Danish Manners - Negotiating Gender and Political
Positioning in Transnational Fields
}

By Nauja Kleist

How do migrants negotiate gender and political positions in a transnational social field? What happens when migrants move between different locations? This paper examines these questions through a case study of a Somali woman and her life in Denmark and Somaliland.

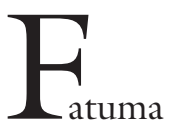

stands in an almost empty apartment in a social housing complex in Copenhagen. ${ }^{1}$ She is excited. In about a month, she will go to Somaliland as she has wanted to do for a long time. Fatuma has never lived in Somaliland but has relatives there and looks forward to going very much. She has many plans. Fatuma wants to go into politics to fight the oppression of women. And, she adds, she plans to paint her new house in bright colours of her own choice, like she did with her apartment in Copenhagen. Fatuma is an outspoken woman, expecting to be taken seriously, no matter who she speaks to. In Somaliland, people say that though Fatuma's heart is made of habhab watermelon - meaning that she is soft and easy to touch, her manners have however become Danish, as she is very straightforward for a woman. 


\section{INTRODUCTION}

In this paper, I analyse gender relations in transnational social fields through a case study of Fatuma, a Somali-Danish woman. Similar to many other contemporary migrants, Fatuma relates to more places than her country of residence. She is part of a larger transnational network within which family relations and political positioning are played out. I examine how Fatuma negotiates gender ideals and pursues political ambitions in different, sometimes interrelated, social spaces in Denmark and Somaliland. Such negotiations are a multifacetted and complex phenomenon, intersecting with other social categories such as social class, religion and ideas of nationality. Furthermore, they are also embedded in different contexts - both local and transnational.

The paper proceeds as follows: I start by presenting some theoretical and methodological reflections before briefly outlining the background of contemporary Somali migration. I then turn to Fatuma, following her from Copenhagen to Somaliland. Finally, I conclude with some reflections about gender and other social positions in transnational social fields.

\section{TRANSNATIONAL SOCIAL FIELDS}

Analysing how gender relations are negotiated and performed in a transnational social field poses a range of challenges. The main theoretical claim in transnational studies is, as migration researchers Peggy Levitt and Nina Glick Schiller write, that it is necessary to rethink "the boundaries of social life" and the concept of society as stretching beyond the borders of nation-states (2004, 1003-1004). Several writers on transnationalism have suggested concepts such as transnational social fields or spaces (e.g. Goldring 1998; Mahler \& Pessar 2001) to capture the multi-locality and simultaneity of migrants' practices across borders. Inspired by Bourdieu, Levitt and
Schiller have proposed the term transnational social field, defined as:

a set of multiple interlocking networks of social relationships through which ideas, practices, and resources are unequally exchanged, organized, and transformed [...] National social fields are those that stay within national boundaries while transnational social fields connect actors through direct and indirect relations across borders $(2004,1009)$.

It is a central point that social fields are of a relational nature and positions are perceived differently by the actors within the field. This is important, especially in relation to studying gender. Because, as Levitt and Schiller also emphasise, migrants engaged in transnational relations are simultaneously relating to (at least) two sets of political, economic and socio-cultural contexts - and thereby possibly shifting positions. In their words:

individuals [may] occupy different gender, racial, and class positions within different states at the same time. Recognising that migrant behaviour is the product of these simultaneous multiple statuses of race, class, and gender makes certain social processes more understandable (2004, 1015, my insertion).

Differential but simultaneous positions in transnational social fields thus complicate positioning and negotiations of gender. An important aspect of this question relates to cultural intelligibility and recognition in different contexts (Ahmed 2003; Butler $1999,2004)$, i.e. how certain positions are perceived as viable and desirable or undesirable or impossible within local and transnational spaces - and how such positions are (attempted to be) negotiated. In the case of Fatuma, how different ideals of femininity are 'done', recognised and evaluated in Copenhagen and Somaliland if you are a black, Muslim woman of Somali origin are examined, and especially how gender inter- 
sects with other categories, such as religion, racialisation, and social class.

The study of Fatuma is part of a larger ethnographic fieldwork project carried out among Somali associational activists in 2003 and early 2004 (Kleist 2007). The fieldwork was mainly carried out in Copenhagen and supplemented with trips to Somaliland and London, which are central hubs in many of the transnational networks that Somalis in Denmark are part of. I interviewed Fatuma in Denmark and Somaliland as well as some of her relatives in all three locations. I have, thus, followed both her and her family network (Marcus 1995) in different locations and in different contexts. These contexts are important to know, because transnational relations are not free-floating but bounded in different structural contexts (cf. Smith \& Guarnizo 1998). Therefore, in the next session, I turn to a short introduction of the Somali diaspora and the reception and settlement of Somalis in Denmark.

\section{THE SOMALI DIASPORA}

Since the eruption of the civil war in 1988 and the disintegration of the Somali state in 1991, Somalis have been displaced almost all over the world and many Somali families are scattered in different countries and on different continents. ${ }^{2}$ This situation has lead researchers, policy makers and Somalis themselves to speak of a Somali diaspora, referring to the global dispersion of Somalis, who - to changing degrees - maintain a sense of belonging, contact and involvement in their erstwhile homeland. Also in 1991, the north-western province of Somalia seceded and declared itself independent as the Republic of Somaliland. ${ }^{3}$ Although Somaliland has since gone through a number of peace processes and democratic election processes, and the area has been relatively peaceful since 1996, no countries have recognised it. Somalia, on the other hand, has continued to be haunted by po- litical instability, humanitarian catastrophes and insurgencies. The political situation and future of Somalia and Somaliland remain a very politically contested question among Somalis, who are divided in relation to this issue. Likewise, the clan system - the patrilineal lineage families that all Somalis are born into - has become reified during the dictatorship and the civil war, meaning that the areas dominated by a clan family often have become their 'home region', regardless of whether they have actually lived there (see Barnes 2006; Lewis 1994; Luling 2006). Somalis who belong to the dominant clan families in Somaliland are thus very often defined by others and themselves as Somalilanders, though they might never have lived in the area.

Many Somalis in the so-called diaspora do indeed remain oriented towards Somalia and Somaliland by following the news, maintaining contact with relatives, remitting money, supporting reconstruction projects or investing in land or business (e.g. Hansen 2007; UNDP 2001). These contributions are indispensable for the local population and there are often huge expectations placed on Somalis abroad to support their relatives in the Horn of Africa. Such expectations also apply to Somalis living in Denmark. The about 17, 000 Somalis in Denmark (including naturalised citizens and descendants) (Immigration Service 2006) are one of the major groups of thirdcountry citizens and by far the biggest African group. Somalis began coming to the country in larger numbers in the middle of the 1990s, following the civil war in Somalia. Their reception has been rather ambivalent with massive negative political and media exposure, especially in the late 1990s and early 2000s (see Fadel, Herik \& Vestergaard 1999; Jørgensen \& Bülow 1999; Kleist 2007). Furthermore, the fact that the Somali group holds the lowest level of employment among all ethnic minority groups in Denmark aggravates their difficult position in Danish society and is a sub- 
ject of outspoken frustration among many Somalis. Still, many Somalis in Denmark are part of transnational networks, regularly remitting money and, in some cases, supporting reconstruction projects. There is also a high number of Somali ethno-national associations, of which some are oriented towards social and cultural issues in Denmark, some support reconstruction in Somalia or Somaliland - and some are involved in both kinds of activities. Fatuma is an example of a person engaged simultaneously in both types of involvement.

\section{FATUMA'S STORY}

Fatuma came to Denmark in the 1980s before large numbers of Somali asylum seekers started to arrive in the country. Fatuma explained that she grew up in a big town in the south of Somalia and that she left the country because of 'political problems'. Having family in the UK, Fatuma was headed toward London, but the flight had a transit stop in Copenhagen and she was therefore told to seek asylum in Denmark. Fatuma told me, "There were not so many refugees when I came to Denmark and only very few women". She continued by adding that it was not difficult to come to Denmark at that time, people were very friendly and treated her well. Her arrival and reception were thus, as she observed, very different from what the Somalis who arrived in the 1990s experienced. Fatuma settled in, pursued a further education and became employed within her field. After a few years, she also met and married her Somali husband, Said, with whom she has three children. The family now lives in a social housing complex in a Copenhagen suburb.

Like many other Somali families, Fatuma's relatives are scattered all over the world and live in the UK, the US, the Gulf States and the Horn of Africa. Fatuma regularly keeps in touch with her closest family through visits, e-mails, and phone calls. Be- cause her relatives are relatively well off, $\mathrm{Fa}$ tuma does not remit money to them, but she and her husband send money to Said's family in Somaliland. Said is also well educated, but - like many other educated Somalis in Denmark - he has not been able to find employment that matches his educational background, which frustrates both of them considerably. Every now and then, however, Said has various assignments in East Africa and works abroad for prolonged periods of time. During these periods, Fatuma is left alone with the responsibility of caring for their children and is thus a de facto single mother. Hence, in spite of the fact that she is in a relatively privileged position in comparison to many other Somali families who experience unemployment, limited education, and dependency on social welfare, she does not live a privileged life compared to the general Danish population.

\section{POLITICAL POSITIONING}

When Fatuma came to Denmark, the civil war had not broken out full scale and Somaliland had not yet come into (contentious) existence. In recent years, however, Fatuma has become increasingly politically interested in Somaliland and has started to voice her position as a political proponent of its international recognition. There might be a number of reasons for this political interest, especially, the dynamics of clan affiliation. While Fatuma emphasises that she does not care much about clan herself, her lineage - which is one of the big clan families in Somaliland - still positions and defines her as a Somaliland woman in the eyes of other people. According to Fatuma, this is exactly what happened a few years ago when she was the subject of gossip from women from other parts of Somalia who claimed that she was an infidel. Fatuma explained:

It's funny, in the beginning we were from all 
over Somalia, but then they [women from other parts of Somalia] started to gossip that we were infidels and all kinds of stuff and I realised that they said ... that I was from Somaliland ... and then they started to say, 'she does not go to the mosque'. But I told them, 'I am very devout, I don't have to go to the mosque'.

Fatuma - a devout Muslim and an assertive, outspoken woman - could not let such accusations go unanswered. She started to emphasise her affiliation with Somaliland, accentuating the distance between Somaliland and other Somali women, pointing to the differences in the political situation and interests. Thus, while Fatuma rejected the accusations of infidel behaviour, she 'accepted' the political position ascribed to her by the other women, using it to consolidate social and political boundaries - playing their game, so to speak. Fatuma's emerging political commitment to Somaliland was thus transnational in its very nature, exemplifying how the Somali civil war and political tensions in the region spill over in diaspora, linking clan affiliation and political orientation to the 'proper' way of practicing Islam in Denmark, though no blood was shed in the Danish context. ${ }^{4}$

Fatuma, for one, became involved in an association for Somaliland women. At the time of my fieldwork, the association had the stated aim of simultaneously furthering integration into Danish society and supporting development in Somaliland while preparing its members for repatriation in the very long term. This double commitment enabled key activists to position themselves as potential actors in Somaliland as well as in Danish society. Due to the overall gender order (cf. Connell 2005) in both Danish and Somali contexts, organising as a women's association made such positions possible, as my broader analysis of Somali associations in Copenhagen has shown (Kleist 2007). Indeed, the SomaliDanish associational scene, to a large de- gree, is gender divided. Many associational activities tend to be for men or women only and many executive committees are exclusively made up of men. This might reflect a gendered time and space economy (cf. Massey 1994), where women are related to the private sphere and men are the politicians' in the public sphere (Farah 2000; Kallehave 2001). Though by no means universal or uncontested - especially given that many Somali women are and have been working outside the home and that one of the most powerful politicians in Somaliland is a woman - these complementary and dichotomous gender ideals remain powerful.

One aspect of associational gender division can be seen as reflecting gender ideals. First, forming a women's association may create a space for action and recognition both in relation to Somali communities as well as to Danish society. Organising as women makes it possible to be recognised as cultural intelligible actors - as decent Muslim women, not collaborating too closely with men - and to be creating positions for speaking out and working in partnership with other associations and actors. Thus, a women's association might be seen as a strategic alternative to collaboration with men who may dominate associations, not leaving much space and initiative for women. For a woman like Fatuma, who quickly becomes impatient with dominant men, and who simultaneously guards her reputation as a devote Muslim, involvement in a women's association has certain advantages because it respects both cultural and religious ideals of gender division and moves beyond the idea of politics as an exclusively male sphere.

Second, ideas about oppressed refugee and Muslim women are widely circulated and gender equality is articulated as crucial for integration into Danish society. In this context, Somali women's associations can easily be recognised as having integrative potential worthy of economic and moral 
support. As result, I will argue that in the context of Danish society, Somali women's associations might fit well with (some) Danish notions of Somali women - the idea of oppressed women versus Danish ideals of gender equality - and that supporting Somali women's associations might be seen as a step towards possible emancipation and democracy à la Danoise. Fatuma and other activists might thereby be recognised as 'good refugee women' in Denmark in the process of integrating themselves vis-à-vis their associational engagement.

Third, forming a Somaliland association can be seen as the establishment of a political actor - as a collective unit enabling its organisers with a capacity to speak for their 'community'. Fatuma might thereby be potentially influencing discussions and decisions regarding Somaliland or the Somali diaspora in a Danish, Somaliland or even international context. Indeed, Fatuma and the other organisers collaborated with NGOs in Denmark and the Horn of Africa, attended international conferences as representatives of their association and organised seminars with a (partly) political agenda in Denmark. Fatuma thereby contributed to the political debate concerning Somalis in Denmark and to political mobilisation for Somaliland. Indeed, she was often explicitly arguing for the autonomy and advancement of Somaliland, positioning her and the association in an overall transnational political field. In this perspective, then, forming or joining an association can be seen as creating a platform for action to realise activities and negotiate positions in different social spaces; positions that might require cultural intelligibility in order to be possible in the first place. I will argue that a successful transnational associational strategy requires that all three aspects are considered. However, as shown below, this is not always so easy, as Fatuma realised while in Somaliland.

\section{Negotiating GENDER AT 'HOME'}

Though Fatuma did not grow up in Somaliland, she was, as already mentioned, affiliated with the region through kinship and clan affiliation. She also owned land in Somaliland, in case, as she put it, she wanted to live there one day. That day had now arrived. Though Fatuma was very excited, she was also nervous. She had lived in Denmark for many years and got used to it and she had actually never lived in Somaliland. Being an ambitious woman, Fatuma wanted to go into politics to promote the status of women and fight against girl circumcision as well as carry out several plans she had for her association. Yet, she was also worried about how she, a woman with her own opinions, would be received. When I asked if she was nervous about going, she reflected:

Yes, a bit, because, you know, as a woman, you have more freedom here than in Somaliland, and I voice my opinion and get involved in all sorts of things. Women don't do that in Somaliland, but then they have to accept me as I am, otherwise I'll go back. I am not going to accept that they interfere in my private life. I have told my husband that I am going to be independent. I would like to help out, but they shouldn't poke their nose in my private affairs.

For Fatuma, life in Denmark was ambivalent. It meant, on the one hand, independence and the ability to maintain a certain degree of privacy, while on the other, it meant exposure to contested and sometimes rather hostile political and media discussions concerning Muslims in general and Somalis in particular (Kleist 2007, see also Andreassen 2005; Hervik 2002). According to Fatuma, she and other Muslims even had to watch their words and deeds very carefully in order to not be denounced as Islamists. For Fatuma, hostility and scepticism towards Islam were thus one of the main barriers of life in Denmark, though 
she appreciated the freedom and privacy found in Danish society.

When I visited Fatuma in Somaliland six months later, she asked me to bring fresh rye bread from Denmark, which she missed like so many other Danes living abroad. She told me that she was happy with the relaxed atmosphere in Somaliland and that she had servants and did not have to do everything herself - a stark contrast to her stressful life in Copenhagen. Her new house was definitely bigger and more comfortable than her apartment in Copenhagen. In Somaliland, Fatuma did not work and was no longer struggling to make ends meet as a de facto single mother. Her skin colour and head scarf did not cause people to look at her suspiciously in the street or make her subject to hostile political or media debates. These points emphasise the relativity of positions and social class in transnational social space, because in Somaliland, Fatuma - and other returnees from the West - can live well, at least as long their savings last or until they get a job with an international NGO or UN agency, as is the strategy for many returnees in Somaliland.

However, it would be wrong to paint too rosy a picture. Life in Somaliland was not that easy after all. Though Fatuma defined herself as a Somalilander, was explicit in her political support regarding the recognition of Somaliland and active in a Somaliland association, she did not always feel at home. Fatuma did not know her way around town, did not know the right people, and did not know how to get things done. She was upset about the poverty and about constantly being asked for money by relatives and even by relatives of relatives, who seemed to believe that she had unlimited economic funds. Fatuma had a hard time saying no to people. She had, I was later told, a heart made of habbab, a heart as soft as watermelon, but her manners had become Danish, direct and straightforward and she asked too many questions. Fatu- ma's worries about life in Somaliland were thus realistic - relatives and neighbours were constantly watching her and there was no way of closing her door and telling them to go away. She not only missed rye bread, but also Danish privacy. Getting into politics also turned out to be difficult, because, as Fatuma explained:

It takes a long time for me, because I cannot accept that I have to find somebody, who knows somebody, who knows somebody. I cannot understand why I cannot go directly or just phone and make an appointment. This is really hard for me - but that's the way things work here. [...] As a woman, you are nothing, you are like in the third or fourth row, you really have to assert yourself and say 'here I am'. Even if there are female ministers, I don't understand how they can cope with it $[\ldots]$ It is really hard to accept and I become so furious that every time I achieve something, they say, 'yes, yes, but whose wife are you?' Then I say, 'why does it matter, when I was the one who managed to do it?'

In the end, unable to get through to local politicians, Fatuma had to give up her political ambitions. Likewise, when she tried establishing a new project for her association, she was turned down because - according to her - nobody cares about a women's association. Fatuma thus sometimes felt out of place in both Denmark and Somaliland due to intersecting ideas about gender, Islam, 'Danishness' and 'Somalilandness'. In a Danish context, her skin colour and religious style of dressing would sometimes make her unrecognisable as a 'real Dane' (cf. Fink-Nielsen \& Kleist 2000) or, in the words of Sara Ahmed (2000), make her recognisable as a stranger, but virtually all women in Somaliland cover their hair and bodies when in public. In Somaliland, however, Fatuma looked like other women, but her outspokenness and directness made her stand out as different in some situations, which means she not seen 
as a 'real' Somaliland woman either. Thus, she sometimes appeared to be 'too Muslim and too Somali' in Denmark but 'too Danish' in Somaliland.

\section{Discussion}

Fatuma's story can be used as a lens for analysing gender and other social positions in a transnational social field. Combining transnational studies with Butler and Ahmed's insights on cultural intelligibility and recognition shows how gender is relationally and contextually defined in different social fields and intersects with ideals about Islam, political orientation, and social class - as well as the antitheses of these ideals. Indeed, some versions of Danish and Somali gender ideals are articulated in opposition to each other, though certain ideas about Somali women might actually reinforce each other, as in the case of women's associations. In Fatuma's case, her political commitment and straightforward manner made her appear as an 'integrated subject' (Hvenegård-Lassen 2005) in Denmark but unintelligible as a 'real' Somali woman in Somaliland and her religious practices in Denmark were subject to gossip from other Somalis as well as general scepticism from Danish society. I will argue that such tensions are further accentuated in the context of the ambivalent reception of Somalis (and Muslims in general) in Denmark and in the context of the Somali civil war, spilling over in to the diaspora, politicising gender and Islam. Gender, religion, and political positioning are, in other words, both local and transnational phenomena. Closely interwoven, these categories constitute an embodied and social battlefield of 'proper' behaviour and social inclusion and exclusion - especially, perhaps, in conflict and post-conflict situations.

In Somaliland, Fatuma's difficulties can be seen as a reflection of the patriarchal gender order where politics is a male sphere, making Fatuma culturally unintelli- gible as a potential political actor. Certainly, there are successful business women and female politicians in Somaliland, but in contrast to Fatuma, they seem to know the right people and how to follow the rules of the game. Another supplementary explanation is thus that political involvement and actual projects in Somaliland require local connections (see also Hansen 2007; Kleist in press) and social capital in the Bourdieu sense of group membership (1986). However, social capital is a local asset, which does not transfer very easily (cf. Faist 2000). Thus, though Fatuma was part of a transnational social field through her different kinds of commitments, she did not necessarily possess the crucial knowledge about how to make things happen the local way and thereby perhaps overcoming gender barriers. Or, in other words, while some migrants might be at home in two or more places, others might find themselves in uneasy positions in both their country of residence and origin, feeling they do not really belong either place.

Finally, analysing Fatuma's situation emphasises the complexity and relativity concerning marginality and privilege in transnational social fields spanning poor and rich countries. Fatuma lived a privileged life in Somaliland with servants and a comfortable house, a life she would never have been able to realise in Danish society. Is she part of an upper-class Somaliland elite or is she a marginalised black Muslim refugee in Denmark? Fatuma was not readily accepted as a 'real' Dane in Denmark or a 'proper' woman in Somaliland. Has she become emancipated according to Danish norms of gender equality or is she oppressed in Somaliland? I hope that I have showed that these options are simplified and need to be looked at from a more nuanced perspective and examined in both transnational and local contexts. Rather than providing eitheror perspectives, we need more complex and multifaceted ways of analysing and asking questions. A transnational perspective chal- 
lenges simplified notions of home, gender, marginality and privilege, demonstrating their contextuality, ambivalence and embeddedness in local and global power structures.

\section{Notes}

1. Fatuma's name and the details of her personal story have been changed for reasons of anonymity. I would like to thank Fatuma for sharing her story with me. I would also like to thank my two anonymous reviewers for insightful comments.

2. Somalis have a long tradition of mobility that goes beyond the civil war. For a more extended version of Somali migration history, see Kleist 2004.

3 . The north-western region coincides with the territory of the former British colony of British Somaliland that merged with the UN protectorate of Somalia in 1960, forming the Republic of Somalia 4. As the ongoing fighting between the supporters of the Islamic Courts and the Somali government forces backed by Ethiopian troops has made tragically clear, the combination of ambitions to rule, clan politics, and Islam sometimes have lethal consequences in Somalia.

\section{REFERENCES}

- Ahmed, Sara (2000): Strange Encounters: Embodied Others in Post-Coloniality. Routledge, London \& New York.

- Andreassen, Rikke (2005): The Mass Media's Construction of Gender, Race, Sexuality and Nationality: An Analysis of the Danish News Media's Communication about Visible Minorities from 1971 - 2004. PhD dissertation, University of Toronto. - Barnes, Cedric (2006): " $U$ dhashay - Ku dhashay: Genealogical and Territorial Discourse in Somali History", in Social Identities 2006/4.

- Bourdieu, Pierre (1986): "The Forms of Capital", in Richardson, John G. (ed.): The Handbook of Theory and Research for the Sociology of Education. Greenwood, New York.

- Butler, Judith (1999): Gender Trouble: Feminism and the Subversion of Identity. Routledge, London \& New York.

- Butler, Judith (2004): Undoing Gender. Routledge, New York \& London.

- Connell, Robert (2005): "Globalization, Impe- rialism, and Masculinities", in Michael S. Kimmel; Jeff Hearn, \& Robert Connell (eds.): Handbook on Studies on Men er Masculinities. SAGE Publications, Thousand Oaks, London \& New Delhi. - Fadel, Ulla Holm; Hervik, Peter, \& Vestergaard, Gitte (1999): "De "besværlige" somaliere", in Peter Hervik (ed.): Den generende forskellighed.

Danske svar på den stigende multikulturalisme.

Hans Reitzels Forlag, Copenhagen.

- Faist, Thomas (2000): The Volume and Dynamics of International Migration and Transnational Social Spaces. Clarendon Press, Oxford.

- Farah, Nurrudin (2000): Yesterday, Tomorrow: Voices from the Somali Diaspora. Cassell, London \& New York.

· Fink-Nielsen, Mette \& Kleist, Nauja (2000): “At bære eller ikke bære tørklæde - er det virkelig spørgsmålet?”, in Kvinder, Køn \& Forskning 2000/3.

. Goldring, Luin (1998): "The Power of Status in Transnational Social Fields", in Michael Peter Smith \& Louis Eduardo Guarnizo (eds.) Transnationalism from Below. Transaction Publishers, New Brunswick, New Jersey.

- Guarnizo, Louis Eduardo \& Smith, Michael Peter (1998): "The Locations of Transnationalism", in Michael Peter Smith \& Louis Eduardo Guarnizo (eds.): Transnationalism from Below. Transaction Publishers, New Brunswick, New Jersey. - Hansen, Peter (2007): Revolving Returnees: Transnational Return among Somalilanders. PhD dissertation, University of Copenhagen, Copenhagen.

- Hervik, Peter (2002): Mediernes muslimer - En antropologisk undersogelse af mediernes dakning af religioner. Council for Ethnic Equality, Copenhagen.

· Hvenegård-Lassen, Kirsten (2005): "Realistic Grown-ups? A Comparative Analysis on How the Formation of an Integrated Subject is Conceived in Sweden and Denmark", in AMID Working Paper Series 2005/44.

- Immigration Service (2006): Tal og fakta på udlendingeomraidet 2005. Immigration Service, Copenhagen.

- Jørgensen, Rikke Egaa \& Bülow, Vibeke Søderhamn (1999): "Ali og de fyrretyve k(r)oner. En analyse af Ekstra Bladets kampagne "fremmede", in Peter Hervik (ed.): Den generede forskellighed. Danske svar på den stigende multikulturalisme. Hans Reitzels Forlag, Copenhagen.

- Kallehave, Tina (2001): "Somali Migrants", in Ethnologia Scandinavica. Vol. 30.

- Kleist, Nauja (2004): "Nomads, Sailors and Refugees: A Brief History of Somali Migration", in Sussex Migration Working Papers 2004/23. 
- Kleist, Nauja (2007): Spaces of Recognition: An Analysis of Somali-Danish Associational Engagement and Diasporic Mobilization. PhD dissertation, University of Copenhagen, Copenhagen.

. Kleist, Nauja (in press): "Somali-Scandinavian Dreaming: When the Diaspora Returns to the Desert”, in Ninna Nyberg Sørensen (ed.): Living Across Worlds: Diaspora, Development and Transnational Engagement. International Organization of Migration, Geneva.

· Levitt, Peggy \& Schiller, Nina Glick (2004):

"Conceptualizing Simultaneity: A Transnational Social Field Perspective on Society", in International Migration Review 2004/3.

- Lewis, Ion M. (1994): Blood and Bone: The Call of Kinship in Somali Society. The Red Sea Press, Lawrenceville, New Jersey.

· Luling, Virginia (2006): "Genealogy as Theory, Genealogy as Tool: Aspects of Somali Clanship", in Social Identities 2006/4.
- Mahler, Sarah. \& Pessar, Patricia R. (2001):

"Gendered Geographies of Power: Analyzing Gender across Transnational Spaces", in Identities:Global Studies in Culture and Power 2001/4. - Marcus, George (1995): "Ethnography in / of the World System: The Emergence of Multi-sited Ethnography", in Annual Review of Anthropology. Vol. 24.

- Massey, Doreen (1994): Space, Place and Gender. Polity Press, Oxford.

. UNDP (2001): Human Development Report, Somalia 2001. United Nations Development Programme, Nairobi, Kenya.

Nauja Kleist, PhD, Project Researcher, Danish Institute for International Studies nkl@diis.dk 